\section{Beley 0., Zamikhovska 0., Stasyuk R.}

\title{
DEVELOPMENT OF THE TOP LEVEL OF THE AUTOMATED SCADA SYSTEM OF FEEDING MOISTURE IN THE SOIL- VEGETATIVE COVER
}

Розроблено верхній рівень системи подачі вологи в грунтово-рослинний покрив з використанням програмного продукту фірми Siemens Simatic WinCC. Виходячи з водно-фізичних властивостей грунтів, розроблено три режими подачі вологи в грунтово-рослинний покрив (ручний, першого та другого типу). Структура розробленої системи - це кількість режимів управління, структура мережі та передачі даних.

Ключові слова: грунтово-рослинний покрив, режими подачі, структура системи, верхній рівень системи.

\section{Introduction}

An important task of irrigated agriculture is the introduction of environmentally safe, water-saving technologies for watering crops.

The solution to this problem is impossible without the creation of perfect automated irrigation systems (AIS). Studies on the search for optimal solutions in the design of gas stations, reconstruction, network identification, leak detection, unauthorized sampling, internally tubular corrosion formations with a lack or uncertainty of the original data have a particular importance.

When solving this class of problems, the main problem is the construction of an automated system that takes into account a large number of factors, uncertainty conditions, and allows the development of scenarios for optimization planning tasks.

The main consideration when developing software in the Step 7 package for the water supply system for soil and vegetation should be given to:

- saving a large amount of water due to the optimal setting of the irrigation process and the absolute absence of a «strait» of water;

- constant monitoring of water flow;

- protection from the prohibition of access to information collection and management;

- real-time monitoring of water supply;

- user-friendly interface.

\section{The object of research and its technological audit}

The object of research is the control and distribution of water in the soil and vegetation cover.

The subject of the study is the development of the top level of the system - this is the man-machine interface SCADA WinCC, which reflects the state of the controlled quantities.

The structural diagram of the water supply system is shown in Fig. 1 [1].

Elements of the structural scheme (Fig. 1):
- I1 - float switch for maximum value;

- I2 - float switch for minimum value;

- I3 - twilight switch;

- I4 - switch for automatic controlled irrigation;

- Q1 - solenoid valve for irrigation of plants type 1 ;

- Q2 - solenoid valve for irrigation of plants type 2 ;

- Q3 - solenoid valve for irrigation of plants type 3.

The basis for constructing the top level of the automated system is the structural diagram (Fig. 1) and the lower level of the system is developed [1].

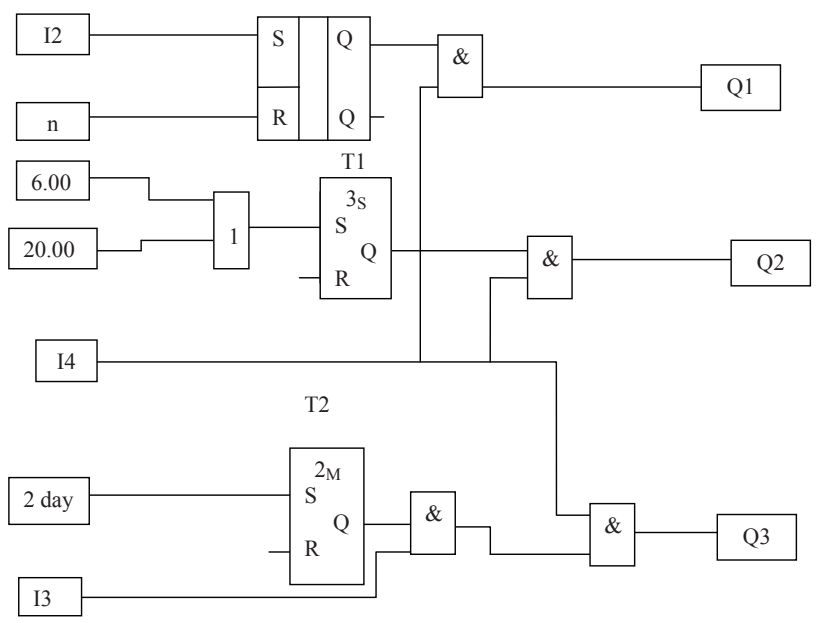

Fig. 1. Structural diagram of the water supply system

Typical shortcomings of the developed system are the impossibility of archiving data and output of emergency messages.

\section{The aim and objectives of research}

The aim of research is provision of soil and vegetation cover with moisture by developing a computerized information system.

To achieve this aim, the following tasks are set:

1. To identify the main shortcomings and problems of existing hardware and software. 
2. To list the theoretical prerequisites for creating the top level of the automated SCADA system of water supply to the soil and vegetation cover.

3. To develop the top level of the water supply system.

\section{Research of existing solutions of the problem}

Automatic systems can work without human intervention and constant maintenance. The most famous manufacturers of this equipment are Hunter, Nelson, Rain Bird and Gardena. Automation here is represented by control panels (controllers) or control computers, including in the intelligent system «smart house». They allow to program the multiplicity, graph, sequence and selection of irrigation objects; take into account weather conditions and control the whole system, sensors (humidity, rain, frosts and others) and solenoid valves of pipelines. The control panel can be connected to sensors and cables from radio control devices.

The sprinkler irrigation system NAAN DAN JAIN (Israel) is known. The water supply is carried out by spraying or splashing the planted area. This watering is suitable for greenhouses, parks, nurseries, flower beds and various horticultural facilities [2].

In [3], the authors propose a system for monitoring the water-physical properties of soils, which consists of two levels: the lower one $[4,5]$, which is represented by four functions FC4 (moisture control of soil), FC8 (value of the useful moisture reserve), FC9 (value of total moisture reserve) and FC10 (value of hard-to-reach moisture reserve) and the top - man-machine interface in SCADA WINCC, reflecting the state of the monitored values (graphical representation, archiving and alarm output) at the selected monitoring point (Fig. 2).

According to Fig. 2, the following notation is given:

1 - functional buttons for displaying the windows of archiving and messages;

2, 3, 4 - general information on the state of the level of flood waters, the amount of atmospheric precipitation and soil moisture;

5, 6 - windows for graphic and numerical archiving of data;

7 - window for displaying messages;

$8,9,10$ - the value of the useful and general moisture reserve, as well as a hard-to-reach reserve of soil moisture.
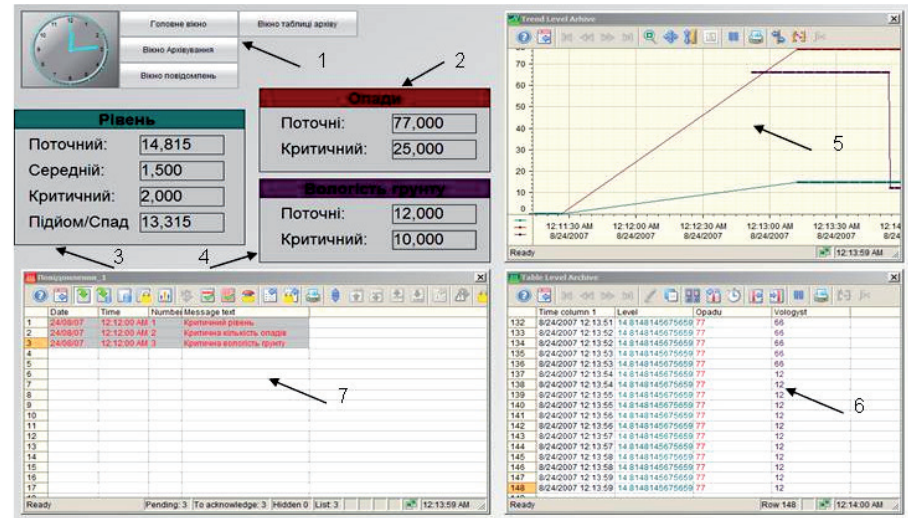

Fig. 2. Working window of the monitoring system of soil properties

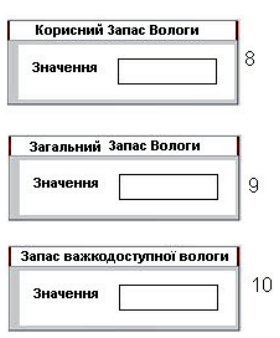

Today, a lot of hardware and technical supply of water to the soil and vegetation cover is known: drip irrigation systems, which are designed for direct water supply to plant roots. The liquid that has got into the roots in this way is assimilated by the plants almost completely. In addition, such watering system significantly reduces water consumption, which is another undeniable advantage of many feeders; automatic irrigation system for greenhouses, which allows to water crops at precisely specified times with a strictly measured amount of water, while its temperature is at the proper level. The system includes a special controller that remembers the date and time of water supply, there are sensors that determine the water temperature, if necessary, give a signal about its heating [6-8].

Authors AGBETUYI Ayoade Felix, OROVWODE Hope. E, AWELEWA Ayokunle. A WARA Samuel.T OYEDIRAN Tobiloba developed an automatic production system based on soil moisture monitoring from the account of their types [9].

In conclusion, it should be noted that among the main ways to solve the problems of existing hardware and software should be identified as follows:

- high economic costs for development and implementation of these systems and equipment;

- cover a narrow research task;

- complexity of automatic irrigation systems;

- complex user interface;

- not taking into account time boundaries;

- about the existing water supply devices, then a considerable amount of electronic components must be used for their manufacture.

\section{Methods of research}

The main materials for research are the analysis of existing automated irrigation systems and literature sources that are used to develop the SCADA system of water supply to the soil and vegetation cover.

The study is carried out using the methods of circuit and system engineering and the involvement of a software product Siemens WinCC v7.0 SP1 (for development of a water supply system).

\section{Research results}

Based on the developed lower level of the system in the STEP 7 software environment, where the type and directory of saving the project files is determined, the top level of the automated SCADA system of water supply to the soil and vegetation cover is developed.

The main focus of software development in the Step 7 package for the water supply system to the soil and vegetation cover is: - saving a large amount of water due to the optimal setting of the irrigation process and the absolute absence of a «strait» of water; - constant monitoring of the water flow;

- protection from the prohibition of access to information collection and management; 
- real-time monitoring of water supply;

- user-friendly interface;

- economic profitability.

SCADA Supervisory Control And Data Acquisition is the main one and currently remains the most promising method of automated control of complex dynamic systems (processes) in vital and critical sectors from the point of view of safety and reliability. It is on the principles of dispatching that large automated systems are built in industry and energy, transport, in the space and military fields, in various state structures.

SCADA process of collecting real-time information from remote points (objects) for processing, analysis and possible control of remote objects. The requirement for real-time processing is conditioned by the need to deliver all the necessary events (messages) and data to the central interface of the operator (dispatcher). At the same time, the concept of real time differs for different SCADA systems. The prototype of modern SCADA systems in the early stages of development of automated control systems are telemetry and signaling systems [10].

The main functions of the SCADA system are:

1. Communication functions:

- between subsystems and SCADA elements;

- with the top-level system on the main and backup communication channels.

2. Information functions:

- functions of collection, primary processing and display of information on the progress of the technological process;

- functions of formation of emergency and warning alarms; - functions of formation of indicators of operation of technological objects;

- functions of recording events, alarms and parameter values.

3. Remote control functions:

- remote control functions by the operator's command;

- functions of automated control by SCADA algorithms;
- functions of automatic protection of process equipment - aggregate protection, station protection, protection algorithms for the entire pipeline.

4. Functions of formation of accounting documents:

- on accounting of technical condition of technological equipment;

- on the accounting of technical condition of software and hardware;

- on accounting for consumption of fuel and energy resources;

- on accounting for balance and quality of marketable products.

5. SCADA component configuration functions include the functions of SCADA basic software and controllers for configuration of automation tools.

Theoretical prerequisites for development of the top level of the automated SCADA system are the principle of operation of the lower level of the water supply system of soil and vegetation cover, taking into account three types of plants:

- type 1 plants are algae in a basin whose water level should be maintained in a certain range;

- type 2 plants must be irrigated in the morning and in the evening for 3 minutes;

- type 3 plants - every second evening for 2 minutes $[10,11]$.

6.1. Development of the top level of SCADA system of water supply to soil and vegetation cover. Development of the top level of the water supply system to the soil and vegetation cover is carried out in the software product of Siemens WinCC.

SIMATIC WinCC is a scalable process visualization system, it has powerful functions for controlling automated processes. WinCC provides all the functionality of SCADA under Windows for all industries - from one user to distributed multiuser systems with redundant servers and global web clients.

SCADA system for monitoring the water supply to the soil and vegetation cover is composed of three monitoring points (three modes of water supply), and the first, the second and the manual ones (Fig. 3).

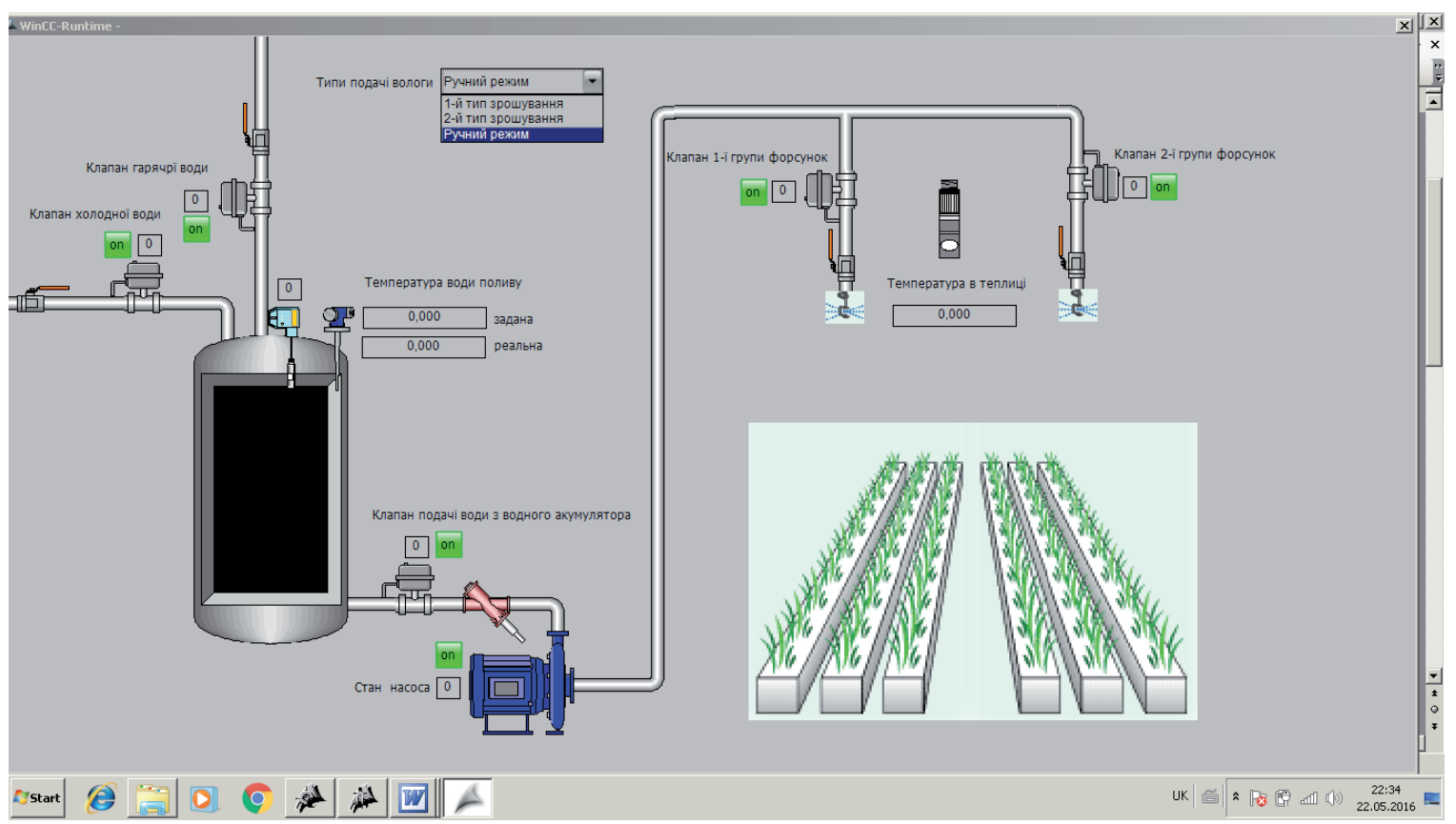

Fig. 3. Window for selecting water supply modes for soil and vegetation cover 
In the manual mode, the control buttons for valves and pumps (On) are displayed and become active. When press once on the button, the valve or pump turns on, and when pressed a second time - it is excluded (Fig. 4).

The first control mode (Fig. 5): level in the tank top (maximum); valves are activated for automatically controlled irrigation.

The second control mode is the water supply in the established time frame (Fig. 6).

So, the system of water monitoring and supply is designed with the help of the man-machine interface of WinCC v7.0 SP1 using a pre-created project in the Simatic Manager software environment. The main result of this work is ensuring optimal and rational water supply to the soil and vegetation cover by developing software.

Advantages of the proposed developed system of supplying water to the soil and vegetation cover in comparison with the existing ones are:

- mobility;

- real-time monitoring;

- user-friendly interface;

- economic profitability.

The developed top level of the supply system can be transferred to greenhouse farms, greenhouses and used in the training courses of disciplines to familiarize with the functional blocks (Boolean algebra) of the software package Step 7, as well as the choice of technical base.

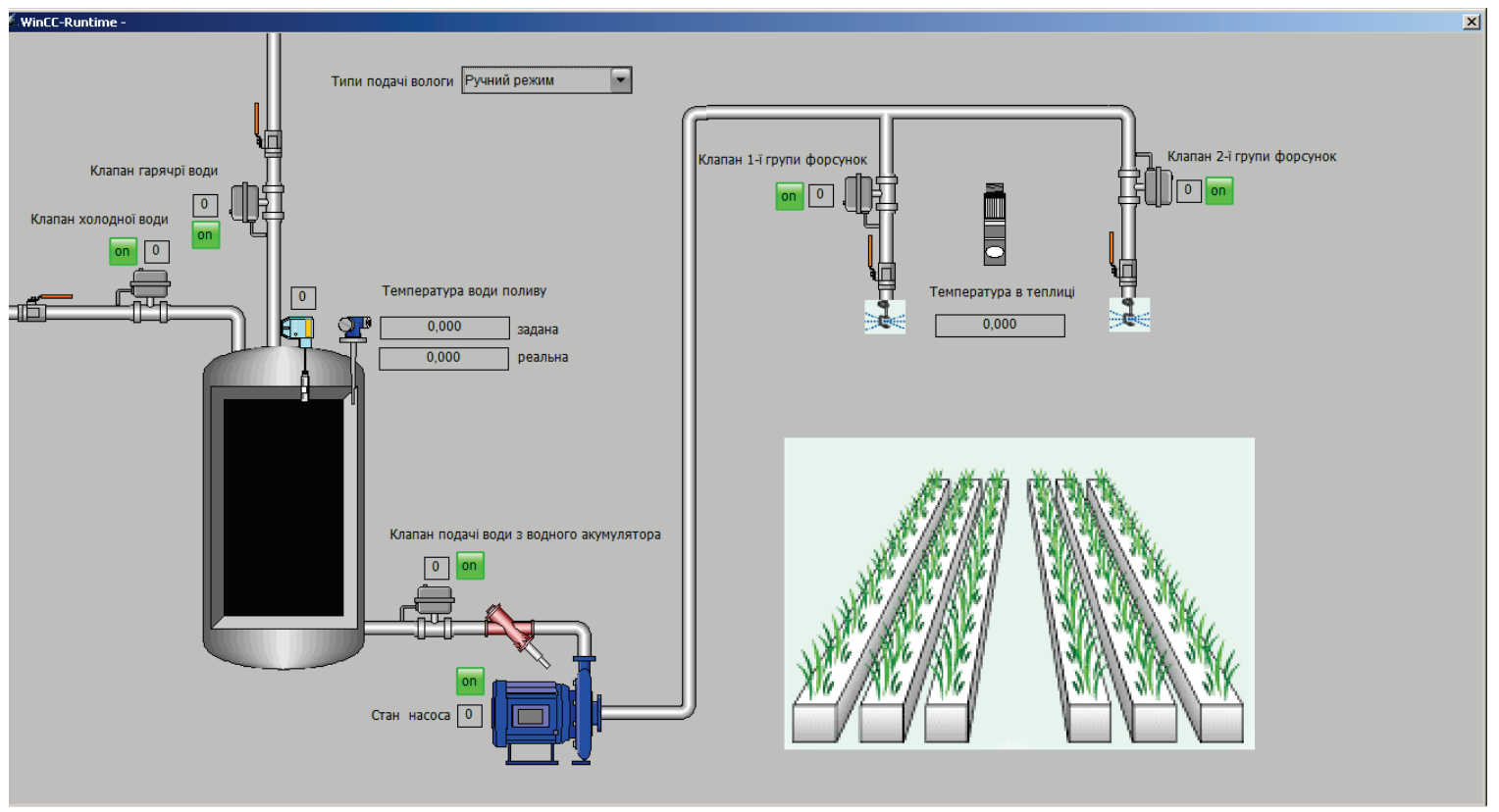

Fig. 4. Manual mode of water supply

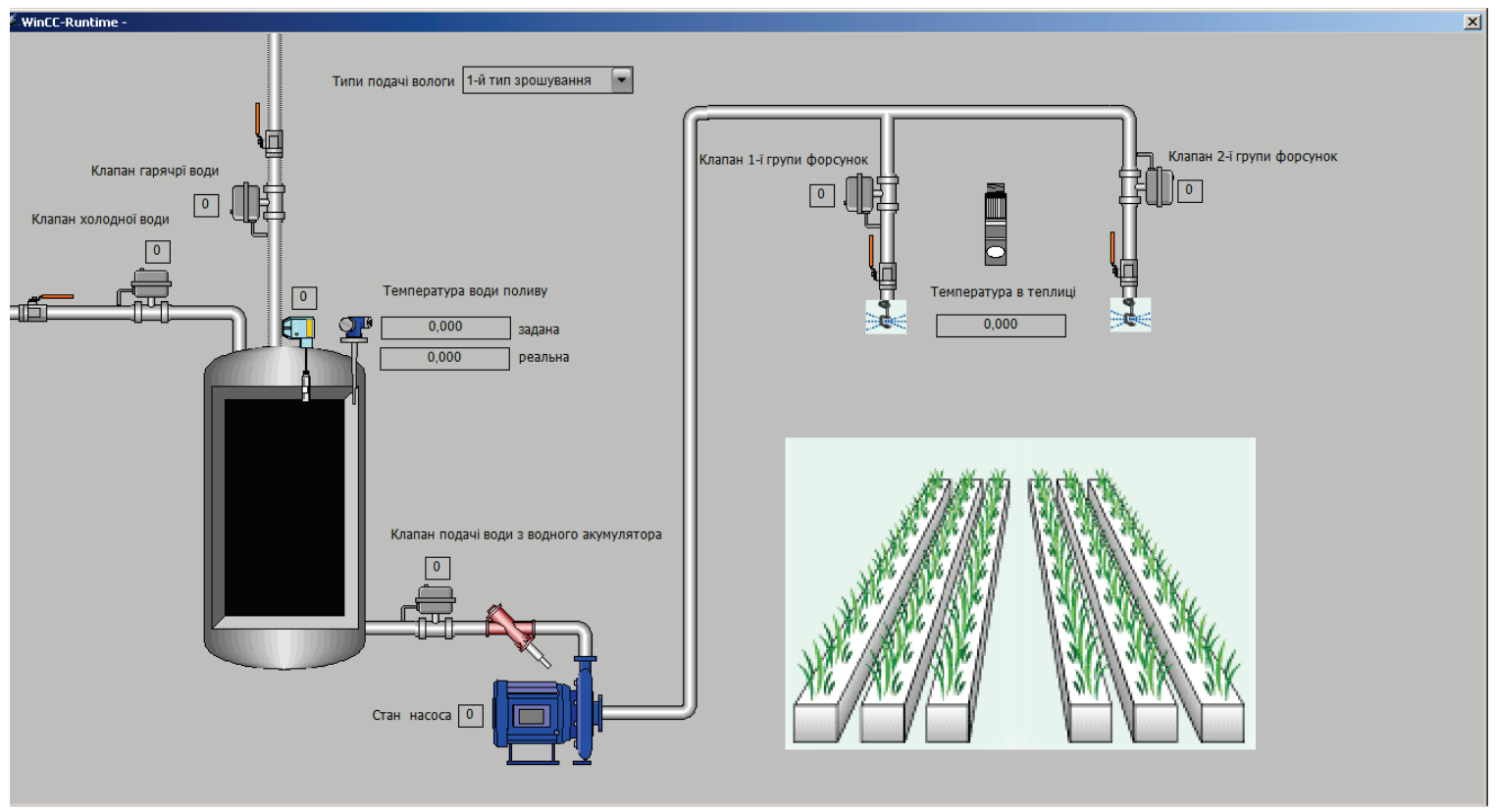

Fig. 5. The first mode of water supply to the soil and vegetation cover 


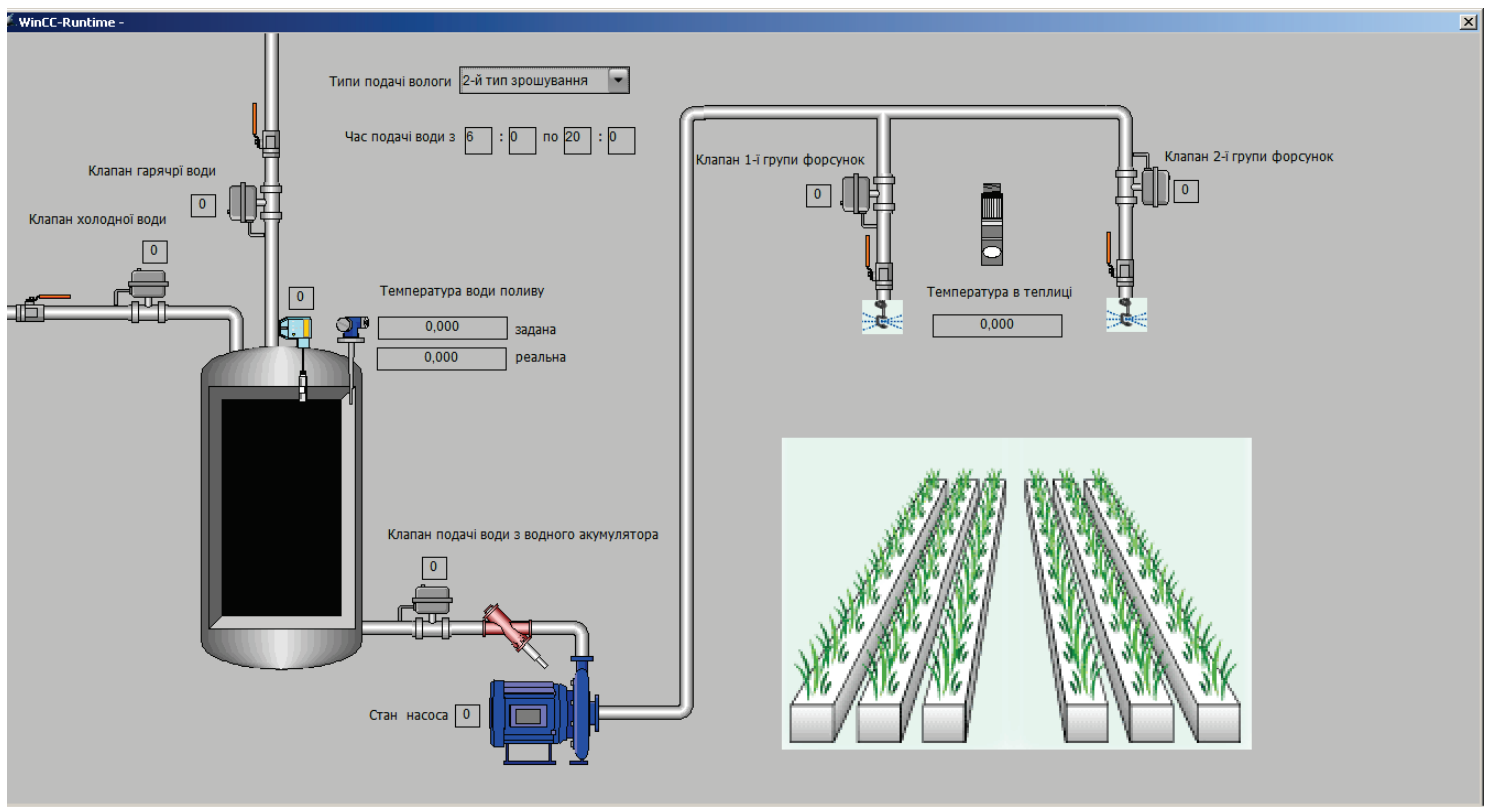

Fig. 6. The second mode of supply of moisture

\section{SWOT analysis of research results}

Strengths. Works on different platforms in real time, the consumer market is large-scale (various higher education institutions or organizations), consumer commitment and user sessions separation, market conditions is a proposal that appears to be one product - an automated system that allows to edit, add, delete additional tags.

Weaknesses. The inability to archive data and output alarms, competitors and financing.

Opportunities. Distributed freely, convenient user interface, the choice of water supply modes, access to the world market.

Threats. The failure of the computer, the sudden exclusion of electricity, scientific and technological progress. This is technology, materials, new perspectives, as well as the demographic environment, which is determined by the composition of the population and its employment.

\section{Conclusions}

1. It is established that the main shortcomings of the existing automated water supply systems to the soil and vegetation cover are the high economic costs of their development and the absence of a choice of control regimes.

2. The structural scheme of the operation principle of the automated water supply system is developed and its lower level served to develop the SCADA water supply system, which:

- allows monitoring of real and current temperatures;

- turn on/off the valves for cold and hot water;

- turn on/off the first or second group of injectors; choose the modes of water supply and monitor the temperature in the greenhouse.

3. It is established that the developed top level of the water supply system allows it to be finalized for the end user in a short time, thanks to the connection of the program's graphical interface, functions and tags, re- sponsible for data output and selection of water supply modes.

\section{References}

1. Zamikhovska, O. L. The lower level of water supply system for land cover [Text] / O. L. Zamikhovska, O. I. Klapoushchak // ScienceRise. - 2016. - Vol. 6, No. 2 (23). - P. 21-27. doi:10.15587/2313-8416.2016.72168

2. Sistemy orosheniia Naan Dan Jain (Izrail') [Electronic resource] // AgroServer.ru - informatsionnaia podderzhka sel'skogo hoziaistva i pishchevoi promyshlennosti. - Available at: \www/ URL: https://agroserver.ru/b/sistemy-orosheniya-naan-dan-jainizrail-132055.htm

3. Klapoushchak, O. I. Rozrobka SCADA-systemy dlia monitorynhu vodno-fizychnykh vlastyvostei hruntiv [Text] / O. I. Klapoushchak, L. O. Shtaier // Proceedings of the V International Internship School-Seminar «Methods and means of diagnostics in technics and socium «MRD TS-2015», November 16-19, 2015. - Ivano-Frankivsk: Ivano-Frankivsk National Technical University of Oil and Gas, 2015. - P. 27-29.

4. Berger, H. Automating with STEP7 in STL and SCL: Programmable Controllers Simatic S7-300-400 with CDROM and disk (revised) [Text] / H. Berger. - Publicist Corporate Publishing, 2001. - $442 \mathrm{p}$.

5. Automation with programs Step 7 LAD and FBD [Electronic resource] // Siemens Russian. - Available at: \www/URL: http://dfpd.siemens.ru/assets/files/infocenter/Documetations/ Automation_systems/STEP7/Berger_STEP7_LAD\&FBD_r.pdf

6. Kapiliarnyi polyv u teplytsi: prystrii, zastosuvannia [Electronic resource] // Remont ta vyroby svoimy rukamy. - 18.03.2015. Available at: \www/URL: http://remontu.com.ua/kapilyarnijpoliv-v-teplici-pristrij-zastosuvannya

7. Systema polyvu na dachi [Electronic resource] // Remont ta vyroby svoimy rukamy. - 18.03.2015. - Available at: \www/URL: http://remontu.com.ua/sistema-polivu-na-dachi

8. SAV-1000 sistema dlia vneseniia ammiachnoi vodi [Electronic resource] // Sunrise-Agro. - Available at: \www/URL: http:// sunrise-agro.uaprom.net/p2931594-sav-1000-sistema.html

9. Agbetuyi, A. F. Design and implementation of an automatic irrigation system based on monitoring soil moisture [Electronic resource] / A. F. Agbetuyi, H. E. Orovwode, A. A. Awelewa, S. T. Wara, T. Oyediran // Journal of Electrical Engineering. Available at: \www/URL: http://www.jee.ro/covers/art.php?i ssue $=$ WK1446219610W56338f5a49ec9 
10. SINEMA Server - Siemens Support. Configuration Manual [Text]: C79000-G8976-C241-01. - Nürnberg, Germany: Siemens AG, 2011. - 215 p. - Available at: \www/URL: https://cache. industry.siemens.com/dl/files/033/52750033/att 105666/v1/ PH_SINEMA-SERVER_76.PDF

11. Shea, N. Siemens vs Allen-Bradley: Function Blocks [Electronic resource] / N. Shea // DMC, Inc. - April 01, 2010. - Available at: \www/URL: https://www.dmcinfo.com/latest-thinking/ blog/articletype/articleview/articleid/171

\section{РАЗРАБОТКА ВЕРХНЕГО УРОВНЯ АВТОМАТИЗИРОВАННОЙ БСАПА-СИСТЕМЫ ЛОДАЧИ ВЛАГИ В ЛОЧВЕННО-РАСТИТЕЛЬНЫЙ IOKPOB}

Разработан верхний уровень системы подачи воды в почвенно-растительный покров с использованием программного продукта фирмы Siemens Simatic WinCC. Исходя из воднофизических свойств почв, разработаны три режима подачи воды в почвенно-растительный покров (ручной, первого и второго типа). Структура разработанной системы - это количество режимов управления, структура сети и передачи данных.

Ключевые слова: почвенно-растительный покров, режимы подачи, структура системы, верхний уровень системы.

Belei Oksana, PhD, Associate Professor, Department of Information and Telecommunication Technologies and Systems, Ivano-Frankivsk National Technical University of Oil and Gas, Ukraine, e-mail: oksana_kl@meta.ua, ORCID: http://orcid.org/0000-0002-2386-4106

Zamikhovska Olena, PhD, Associate Professor, Department of Information and Telecommunication Technologies and Systems, IvanoFrankivsk National Technical University of Oil and Gas, Ukraine, ORCID: http://orcid.org/0000-0001-7123-4080

Stasyuk Roman, PhD, Associate Professor, Department of Information and Telecommunication Technologies and Systems, IvanoFrankizsk National Technical University of Oil and Gas, Ukraine, ORCID: http://orcid.org/0000-0002-4724-6118

\section{Bahakov R. \\ USING OF METHOD OF REPLACEMENT OF INPUT VARIABLES IN MICROPROGRAM FINITE-5TATE MACHINE WITH DATAPATH OF TRANSITIONS}

Запропоновано використовувати відомий метод заміни вхідних змінних для оптимізащіі апаратурних витрат у мікропрограмному автоматі з операційним автоматом переходів. Метод дозволяє використовувати для синтезу схеми пристрою гетерогенний елементний базис, що сприяє зменшенню апаратурних витрат в схемі автомата. В результаті застосування даного методу розроблено нову структурну модель автомата, для якої визначені критерії ефективності в порівнянні зі структурою-прототипом.

Ключові слова: мікропрограмний автомат, операчійний автомат переходів, заміна вхідних змінних, оптимізащія апаратурних витрат.

\section{Introduction}

One of the central parts of modern computing systems is a control unit whose characteristics largely determine the characteristics of the system as a whole [1,2]. The increase in the complexity of computing tasks observed today increases the requirements for the speed of computing systems. One way to improve the speed of control units is to use highly effective structural solutions, one of which is a microprogram finite-state machine (FSM) [2]. FSM with a canonical structure, along with high speed, is characterized by high hardware amount for implementing the logical circuit of the device $[2,3]$. This makes it urgent to develop new structures and methods for synthesizing MPA, aimed at hardware amount optimization while maintaining an acceptable speed.

At present, many methods of FSM optimization leading to various structural realizations are known [3-6]. One of these methods is the method of replacement of input variables, which makes it possible to reduce the number of different Boolean terms in the system of equations for the FSM transition functions [5, 6]. Another structural solution is a microprogram finite-state machine with datapath of transitions (FSM with DT), in which the transition function is represented as a set of partial functions and has a schematic interpretation in the form of a datapath $[7,8]$.

In works $[2,5,6]$ the possibility of joint use of various optimization methods, allowing under certain conditions to increase the efficiency of the resulting FSM structures in terms of hardware amount, is shown. With regard to the microprogram finite-state machine with datapath of transitions, the application of known methods of hardware amount optimization is unexplained for today.

\section{The object of research and its technological audit}

The object of this research is a microprogram finite-state machine with datapath of transitions [7, 8], the structural diagram of which is shown in Fig. 1 and in this paper is denoted by symbol $U_{1}$. 